\title{
Üniversite Sınavına Hazırlanan Gençlerin Covid-19 Korkusunun Öğrencilerin Tükenmişlik ve Anksiyetelerine Etkisi
}

\section{The Effect of Covid-19 Fear of Youth Preparing for University Exam on Students' Burnout and Anxiety}

Melike YAVAŞ ÇELIKK*iD

Atıf Yapmak İçim: Yavaş Çelik M. Üniversite sınavına hazırlanan gençlerin Covid-19 korkusunun öğrencilerin tükenmişlik ve anksiyetelerine etkisi. Van Sag Bil Derg 2021, 14,(1): 19-28. https://doi.org/10.52976/van saglik.760062.

Geliş Zamanı: 29/06/2020

Kabul Zamanı: 30/01/2021

Basılama Zamanı: 30/04/2021

1 Kilis 7 Aralık Üniversitesi, Yusuf Şerefoğlu Sağlık Bilimleri Fakültesi. Hatay, TÜRKIYYE.

* Sorumlu yazar:Melike YVAŞ ÇELIK; E-mail: www com tr@hortmail.com.

\section{ÖZET}

Amaç: Bu çalışmada üniversiteye giriş sınavına hazırlanan gençlerin covid-19 korkusu yaşamalarının tükenmişlik ve anksiyetelerine etkisini incelemek amaçlanmıştır.

Materyal ve Metot: Çalışmaya 18-20 yaş arasında bir ilde etüt merkezinde üniversiteye giriş sınavına hazırlık yapan sosyal medya arayıcılığıyla ulaşılabilen gönüllü 100 öğrenci katılmıştır. Verilerin toplanması için, soru formu, Covid-19 Korkusu Ölçeği (CKÖ), Yaygın Anksiyete Bozukluğu Ölçeği (YABÖ), Maslach Tükenmişlik Envanteri-Öğrenci Formu(MTEÖ) kullanılmıştır. Analizler SPSS programında, yüzdelik alma, t testi, korelasyon analizi kullanılarak yapılmıştır.

Bulgular: Katılımcıların çoğunun covid-19 pandemi süreci nedeniyle sınava hazırlanma süreçlerinin(\%90), sosyal ilişkilerinin(\%93), psikolojik durumlarının(\%87) olumsuz etkilendiği, aile ilişkilerinin(\%54) ise olumlu etkilendiği belirlenmiştir. Ayrıca, Öğrencilerin CKÖ ile MTEÖ puanları arasında zayıf, CKÖ ve YABÖ puanları arasında orta düzeyli pozitif yönde bir ilişki olduğu belirlenmiştir.

Sonuç: Öğrencilerin covid-19 korkusu yaşadıkları ve bu korkunun anksiyete ve tükenmişlikle ilişkili olduğu belirlenmiştir.

Anahtar Kelimeler: Covid-19, Korku, Anksiyete, Tükenmişlik.

\begin{abstract}
Objective: In this study, it was aimed to examine the effect of young people who are preparing for the university entrance exam to experience burden of covid-19 on burnout and anxiety.

Materials and Methods: 100 volunteers, who could be reached through the study of social media preparing for the university entrance exam in the study center in a city between the ages of 18-20, participated in the study. Questionnaire form, Covid-19 FearScale (CKD), Common Anxiety Disorder Scale (GAD), Maslach Burnout Inventory-Student Form (MTES) were used to collect data. Analyzes were made using SPSS program, percentage taking, $\mathrm{t}$ test, and correlation analysis.

Results: It was determined that most of the participants $(90 \%)$, social relationships $(93 \%)$, psychological states (87\%), family relations (54\%) were negatively affected due to the covid-19 pandemic process. In addition, it was determined that there was a weak positive correlation between the students' WISO and MTET scores, and a moderate positive correlation between the WISO and HIS scores.

Conclusion: It was determined that the students experienced covid-19 fear and this fear was associated with anxiety and burnout.
\end{abstract}

Keywords: Covid-19, Fear, Anxiety, Burnout

\section{GíRiş}

Çin'nin Wuhan kentinde 2019 Aralık ayında ortaya çıan koronovirüs (Covid-19) enfeksiyonu tüm dünyayı etkisi altına almıştır ve tüm insanlığı olumsuz etkilemiştir (Ho ve ark., 2020). Koronovirüs (Covid-19), Şiddetli Akut Solunum Sendromu (SARS) ve Orta Doğu Solunum Sendromuna (MERS) sebep olan virusler ile aynı gruba aittir. Virus ciddi akut solunum yolu enfeksiyonlarına sebep olmakta, asemptomatik, hafif ya da şiddetli semptomatik olarak seyretmektedir (Epidemiology Working Group, 2020; Huang ve ark.,2020). Mart ayında koronovirüs (COVID -19) DSÖ tarafından pandemik bir salgın olarak ilan edilmiştir. DSÖ'nün son verilerine göre koronovirus (covid-19)'un 213 ülkede görüldüğü bildirilmiştir (WHO, 2020). Ülkemizde de mart ayında görülmeye başlanmıştır ve Türkiye'de son durum 
2.338.593 toplam test yapılmış, toplam vaka sayısı 170.132, toplam ölü sayısı 4.692'e ulaşmıştır (T.C. Sağlık Bakanlığı, 2020). Salgının ilk aşamasında, uzmanlar fiziksel sağlığı korumanın yollarını açıklanmıştır. Daha sonra, hastalık yayıldıkça, ruh sağlığını korumanın önemini de vurgulamaya başlanmıştır (Bakioğlu ve ark., 2020).

Üniversiteye giriş sınavına hazırlanan gençler bu pandemi sürecinden ruhsal olarak etkilenen önemli bir gruptur. Covid-19 salgın süreci öncesinde yapılan çalışmalarda Türkiye 'de üniversiteye giriş s1navına hazırlanan birçok öğrencinin kayg1, benlik saygısında azalma, bireysel baş etmede yetersizlik gibi durumlar yaşadığı ortaya konmuştur. Ayrıca öğrencilerin ve ailelerin üzerinde büyük bir baskı oluşturduğu, hayatlarının merkezine sınav kayg1sının yerleştiği bilinmektedir (Kutsal ve Bilge, 2012; Özbaş ve ark., 2012; Kaçan ve ark., 2015).

Covid-19 pandemisi gençlerin normal zamanda bile zorluk yaşadığı sınava hazırlık döneminde karşımıza büyük bir sorun olarak çıkmıştır. Bu pandemi sürecinde öğrencilerin önüne bir de ölümcül bir hastalık tehlikesi çıktığında (covid-19) yaşanılacak olumsuzlukları belirlemenin ergen sağlığ1 için gerekli olduğu öngörülmüştür. Olası riskleri önceden bilip ergenlerin gelişim dönemi hakkında yeterli donanıma sahip çocuk sağlığı ve hastalıkları hemşirelerinin salgın sürecinde ergenlere destek sağlayabilecek en iyi meslek grubudur. Ayrıca çalışmadan çıkacak sonuçlar ışı̆̆ında bu hasta grubu daha iyi analiz edilebilir ve hemşireler tedavi ve bakım sürecinde ve ergen sağlığını korumaya yönelik önlemlerin alınması hususunda daha donanimlı hizmet sunabilirler. Bu nedenle, verilecek hizmet kalitesini arttırmak ve ergen sağlığını korumak için çalışmada Üniversite Sınavına Hazırlanan Gençlerin Covid-19 Korkusunun Öğrencilerin Tükenmişlik Duygularına ve Anksiyetelerine Etkisini incelemek amaçlanmıştır.

\section{MATERYAL ve METOT}

Araştırmanın Tipi: Tanımlayıcı ve kesitsel bir çalışmadır

\section{Araştırmanın Soruları}

1-Öğrencilerin covid-19 korkusu yaşama durumları nedir?

2- Gençlerin Covid-19 korkusu ile tükenmişlik durumlarını arasındaki ilişki nasıldır?

3-Gençlerin Covid-19 korkusu ile anksiyete durumlarını arasındaki ilişki nasıldır?

Araştırmanın Evreni ve Örneklemi: Evreni Gaziantep ilindeki bir etüt merkezinde bulunan üniversite sınavina hazırlanan öğrenciler $(n=180)$ oluştururken, örneklemi ise sosyal medya kullanımı olan ve çalışmaya gönüllü katılan gençler $(n=100)$ oluşturmuştur.

\section{Araştırmanın Verilerinin Toplanması:}

Araştırmanın verileri salgın nedeniyle Haziran-Temmuz aylarında uzaktan telefon görüşmesi ve Google formlarda oluşturulan soru formu, Yaygın Anksiyete Bozukluğu Ölçeği, Maslach Tükenmişlik Envanteri-Öğrenci Formu, Covid-19 Korkusu Ölçeği ile toplanmıştır. Katılımcılara gönderilen formlar tamamen katılımcının onayı doğrultusunda doldurulmuştur.

\section{Soru formu}

Araştırmacı tarafından oluşturulan demografik veriler ve covid-19 ile ilgili soruları içeren 29 sorudan oluşmaktadır.

\section{Yaygın Anksiyete Bozukluğu Ölçeği (YABÖ)}

YAB-7 ölçeği yaygın anksiyete bozukluğunu DSM IV-TR kriterlerine göre ölçmektedir. YAB-7 kendini değerlendirme türü bir ölçektir. Dört (0-3) puanlı Likert tipli ölçek ( $0=$ hiç, $1=$ birçok gün, $2=$ günlerin yarısından fazlasında, $3=$ hemen hemen her gün) YAB-7' nin 7 maddesini ölçmektedir. 
Ölçekten alınabilecek puan 0 ile 21 arasındadır. 0-4 arası hafif, 5-9 arası orta dereceli, 10-14 arası yüksek, 15-21 arası puan ise ciddi anksiyete olarak değerlendirilmiştir. YAB-7 toplam puanı için 8 kesme değeri olası YAB tanısı için eşik değer olarak belirlenmiştir. Ölçek Türkçe'yeKonkan ve ark.(2013) tarafından uyarlanmıştır (Konkan ve ark.,2013).

\section{Maslach Tükenmişlik Envanteri-Öğrenci Formu (MTEÖ)}

MTE-ÖF, Schaufeli ve ark. tarafından 2002 senesinde Maslach Tükenmişlik Ölçeği genel formu esas alınarak öğrencilerin üzerinde uygulanmak üzere geliştirilmiş ve Çapri, Gündüz ve Gökçakan tarafından 2011 yılında Türkçe'ye uyarlaması yapılarak, geçerlik ve güvenirliği sınanmıştır. Ölçek yedi dereceli öz bildirime dayanmış olan Likert tipi bir ölçek olarak 16 sorudan ve üç alt ölçekten oluşmaktadır. Uygulamada, MTÖ-ÖF'nin alt ölçekleri ayrı ayrı puanlanmakta ve değerlendirilmektedirler. "Tükenme" ve "duyarsızlaşma" alt faktörlerinde alınan yüksek puanlar; diğer taraftan, "yetkinlik" alt faktöründe alınan düşük puanlar tükenmişliğin olduğunu göstermektedir. Ölçek Çapri ve ark.(2011) tarafından Türkçe' ye uyarlanmıştır (Çapri ve ark., 2011).

\section{Covid-19 Korkusu Ölçeği (CKÖ)}

Tek boyut ve 7 maddeden oluşmaktadır. Ölçeğin değerlendirilmesi: Ölçekte ters madde bulunmamaktadır. Ölçeğin tüm maddelerinden alınan toplam puan bireyin yaşadığı Koronavirüs (Covid-19) korkusu düzeyini yansıtmaktadır. Ölçekten alınabilecek puanlar 7 ile 35 arasında değişmektedir. Ölçekten alınan yüksek puan yüksek düzeyde Koronavirüs korkusu yaşamak anlamina gelmektedir. Ölçek Ahorsu ve ark.(2020) tarafından oluşturul muştur. Ölçek Bakioğlu ve ark.(2020) tarafından da Türkçe'ye uyarlanmıştır. (Ahorsu ve ark., 2020; Bakioğlu ve ark.,2020).

\section{Verilerin Analizi}

Verilerin analizinde SPSS programinda uygulanan pearson korelasyon analizi, bağımsız gruplarda $t$ testi, frekans analizi (yüzdelik alma) yöntemleri kullanılmıştır.

\section{Araştırmanın Etik Yönü}

Araştırmanın yapılabilmesi için Kilis 7 Aralık Üniversitesi Etik Kurulu'ndan 15.06.2020 tarihinde (2020/15 izin numarası) izin alınmıştır. Dijital olarak hazırlanan formada araştırmanın amac1, katıl1cıya yarar ve zararı belirtilerek gönüllülük esas alınmıştır. Bu çalışma, Helsinki Deklerasyonu Prensipleri'ne uygun bir biçimde planlanmış ve yapılmiştır.

\section{BULGULAR}

Katılımcıların 18-20 yaş arasında olduğu ve yaş ortalamalarının $18.46 \pm 0.9$ olduğu, çoğunun ka$\operatorname{dın}(\% 73)$, gelir durumlarının orta halli(\%65), çekirdek ailede yaşadıkları(\%67), eşit ağırlık bölümünden sinava hazırlandıkları(\%39), 1 yıldır sinava hazırlandığı(\%52) belirlendi(Tablo 1).

Katılımcıların çoğunun covid-19 pandemi süreci nedeniyle sınava hazırlanma süreçlerinin(\%90), sosyal ilişkilerinin(\%93), psikolojik durumlarının(\%87) olumsuz etkilendiği, aile ilişkilerinin(\%54) ise olumlu etkilendiği belirlendi. Ayrıca, öğrencilerin \%70'nin covid-19 olma kaygısı yaşadığ1 ve $\% 40$ 'nın bu kaygı nedeniyle sinava girmeyi düşünmediği belirlendi. $\mathrm{Bu}$ süreçte öğrencilerin \%3'nün ve yakınlarının \%25'nin covid-19 tanıs1 aldığı, \%95'nin evde kalma kısıtlılığına uydukları

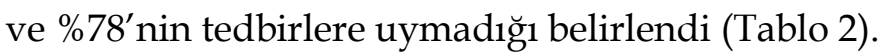

Öğrencilerin CKÖ ile MTEÖ puanları arasında zayıf, CKÖ ve YABÖ puanları arasında orta düzeyli pozitif yönde bir ilişki olduğu belirlendi (Tablo 3)(Şekil 1 ve Şekil 2). 
Tablo 1. Katılımcıların demografik verilerinin analizi

\begin{tabular}{lll}
\hline \hline Veriler & $\mathbf{n}$ & $\%$ \\
\hline \hline Yaş & & \\
18 yaş & 49 & 49 \\
19 yaş & 29 & 29 \\
20 ve üzeri yaş & 22 & 22 \\
Cinsiyet & & \\
\hline Kadın & 73 & 73 \\
Erkek & 27 & 27 \\
Ekonomi & & \\
\hline İyi & 23 & 23 \\
Orta & 65 & 65 \\
Kötü & 12 & 12 \\
Aile tipi & & \\
\hline Çekirdek aile & 67 & 67 \\
Geniş aile & 29 & 29 \\
Parçalanmış aile & 4 & 4 \\
Bölümü & & \\
\hline Sayısal & 32 & 32 \\
Eşit ağırlık & 39 & 39 \\
Sözel & 12 & 12 \\
Yabancı dil & 17 & 17 \\
Sinava hazırlanma süresi & & \\
\hline 1 yıl & 52 & 52 \\
2 ve daha fazla yıl & 48 & 48 \\
Toplam & 100 & 100 \\
\hline \hline & & \\
\hline & & \\
\hline & & \\
\hline
\end{tabular}


Tablo 2. Öğrencilerin covid-19 sürecine yönelik sorulara yanıtları

\begin{tabular}{|c|c|c|}
\hline Veriler & $\mathbf{n}$ & $\%$ \\
\hline \multicolumn{3}{|c|}{ Sınava hazırlanma sürecine etkisi } \\
\hline Olumsuz & 90 & 90 \\
\hline Olumlu & 10 & 10 \\
\hline \multicolumn{3}{|c|}{ Sosyal ilişkilerine etkisi } \\
\hline Olumsuz & 93 & 93 \\
\hline Olumlu & 7 & 7 \\
\hline \multicolumn{3}{|c|}{ Aile ilişkilerine etkisi } \\
\hline Olumsuz & 46 & 46 \\
\hline Olumlu & 54 & 54 \\
\hline \multicolumn{3}{|c|}{ Psikolojik durumlarına etkisi } \\
\hline Olumsuz & 87 & 87 \\
\hline Olumlu & 13 & 13 \\
\hline \multicolumn{3}{|c|}{ Covid-19 olup sınava girememe kaygısı yaşanması durumu } \\
\hline Evet & 70 & 70 \\
\hline Hayır & 30 & 30 \\
\hline \multicolumn{3}{|c|}{ Covid-19 olma korkusu ile sınava girmemeyi düşünme durumu } \\
\hline Evet & 40 & 40 \\
\hline Hayır & 60 & 60 \\
\hline \multicolumn{3}{|c|}{ Covid-19'un pozitif olma durumu } \\
\hline Evet & 3 & 3 \\
\hline Hayır & 97 & 97 \\
\hline \multicolumn{3}{|c|}{ Yakınında covid-19 pozitif olması durumu } \\
\hline Evet & 25 & 25 \\
\hline Hayır & 75 & 75 \\
\hline \multicolumn{3}{|c|}{ Evde kalma kısıtlılığına uyma durumu } \\
\hline Evet & 95 & 95 \\
\hline Hayır & 5 & 5 \\
\hline \multicolumn{3}{|c|}{ Tedbirlere uyma } \\
\hline Evet & 22 & 22 \\
\hline Hayır & 78 & 78 \\
\hline
\end{tabular}


Tablo 3. Covid-19 korkusu ile tükenmişlik ve anksiyete ilişkisi

\begin{tabular}{lllll}
\hline \hline & \multicolumn{2}{c}{ MTEÖ } & & YABÖ \\
\cline { 2 - 4 } Ölçekler & $\mathrm{r}$ & $\mathrm{p}$ & $\mathrm{r}$ & $\mathrm{p}$ \\
CKÖ & 0.24 & 0.014 & 0.48 & 0.000 \\
Toplam & $\mathrm{N}=100$ & & & \\
\hline \hline
\end{tabular}

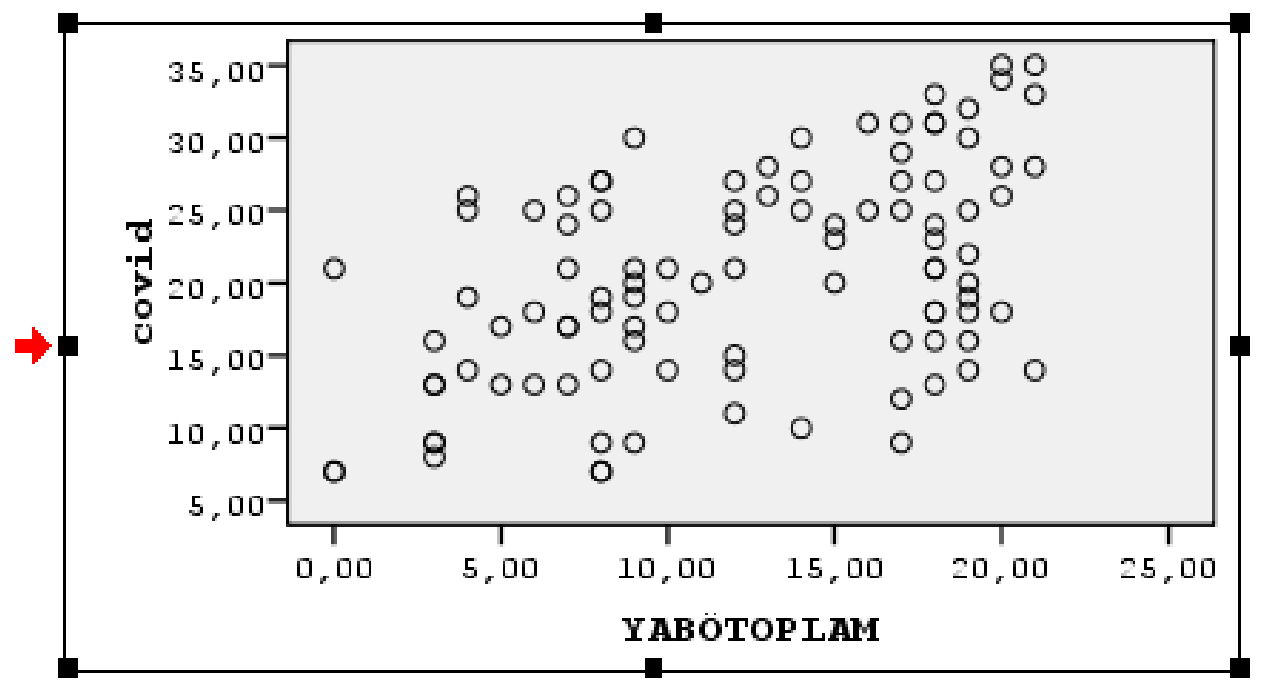

Şekil 1.Covid korkusu ile anksiyetenin ilişkisi

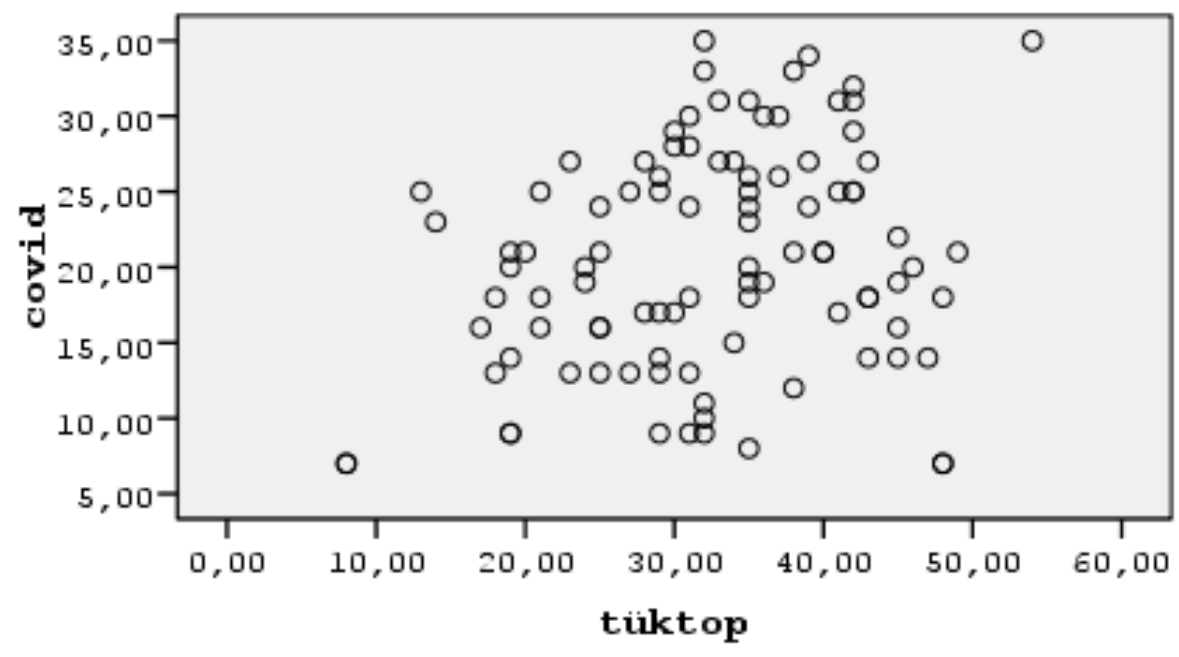

Şekil 2.Covid korkusu ile tükenmişliğin ilişkisi

Öğrencilerin YABÖ puanlarının kesme puanlarına göre MTEÖ ve CKÖ puanları arasında anlamlılık olduğu YABÖ puanları yüksek olan öğrencilerin
MTEÖ ve CKÖ puanlarının yüksek olduğu belirlendi(Tablo 4).Öğrencilerin sinava hazırlanma yıllarına göre MTEÖ, CKÖ ve YABÖ puanlarını karşı- 
laştırdığımızda 2 ve daha fazla yıldır hazırlanan öğrencilerin puanlarının 1 yıldır hazırlık yapan öğrencilere göre daha yüksek olduğu ancak, anlamlı oranda yüksek puanın CKÖ için olduğu belirlendi (Tablo 5).

Tablo 4. Anksiyete durumlarına göre covid-19 korkusu ve tükenmişlik duygusu

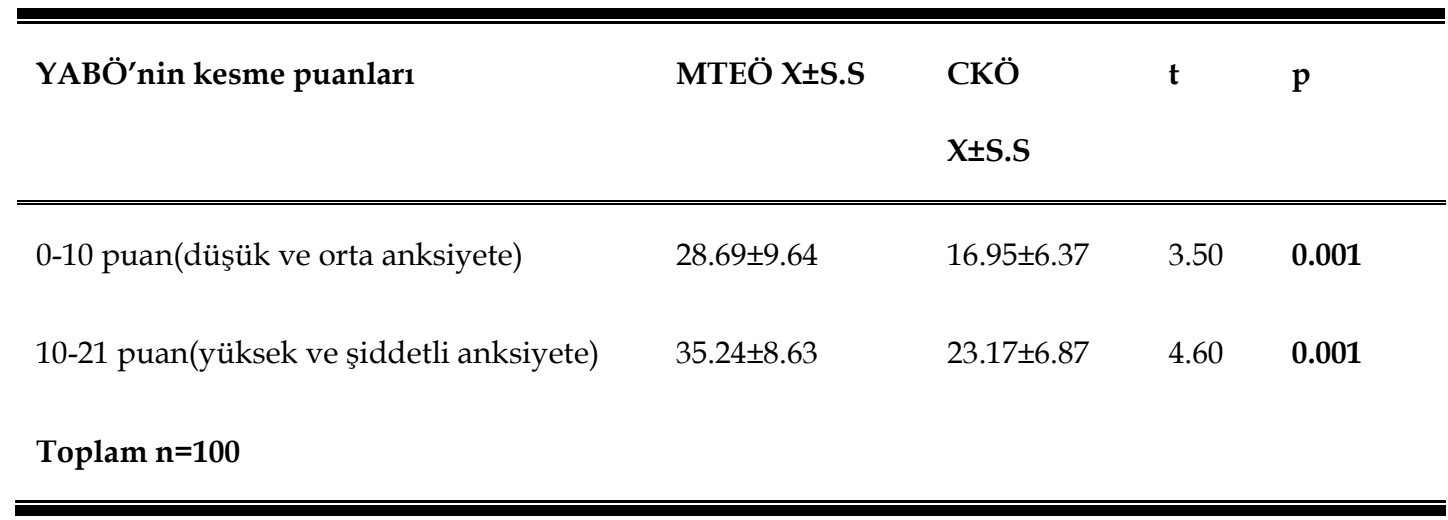

Tablo 5. Öğrencilerin sınava hazırlanma yıllarına göre MTEÖ, CKÖ ve YABÖ puanlarının karşılaştırilmasi

\begin{tabular}{|c|c|c|c|c|c|}
\hline Ölçekler & 1 y1l & 2 ve daha fazla yıl & Ölçeklerin toplam & $\mathbf{t}$ & $\mathbf{p}$ \\
\hline & $\mathrm{X} \pm \mathrm{S} . \mathrm{S}$ & $\mathrm{X} \pm \mathrm{S} . \mathrm{S}$ & $\mathrm{X} \pm \mathrm{S} . \mathrm{S}$ & & \\
\hline MTEÖ & $31.42 \pm 9.48$ & $33.55 \pm 9.76$ & $32.41 \pm 9.62$ & 1.08 & 0.27 \\
\hline CKÖ & $18.96 \pm 7.14$ & $22.43 \pm 7.17$ & $20.56 \pm 7.32$ & 2.41 & 0.01 \\
\hline YABÖ & $11.88 \pm 6.12$ & $12.67 \pm 5.86$ & $12.25 \pm 5.98$ & 0.65 & 0.51 \\
\hline
\end{tabular}

\section{TARTIŞMA}

Katılımcıların 18-20 yaş arasında olduğu ve yaş ortalamalarının $18.46 \pm 0.9$ olduğu, çoğunun kadın (\%73), gelir durumlarının orta halli (\%65), çekirdek ailede yaşadıkları (\%67), eşit ağırlık bölümünden sinava hazırlandıkları (\%39), 1 yıldır sinava hazırlandığg (\%52) belirlenmiştir (Tablo 1).

Pandemi sürecinde durumu kontrol altına alabilmek için eğitim veren tüm kurumlar kapatıldı ve öğrenciler ev kisıtlamasına tabi tutuldu. Bu durum öğrencilerin eğitim ve öğretimlerinde aksaklıklara neden olmuştur (Sahu, 2020; Viner ve ark., 2020; Wang ve ark., 2020). Öğrenciler çok zor zamanlardan geçmiş pandeminin verdiği kaygı ve korkuların yanında geleceklerini oldukça etkileyecek üniversi- teye giriş sınavında başarılı olamama endişesine kapılmıştır.

Çalışma sonuçlarına göre katılımcıların çoğunun covid-19 pandemi süreci nedeniyle sınava hazırlanma süreçlerinin (\%90), sosyal ilişkilerinin (\%93), psikolojik durumlarının (\%87) olumsuz etkilendiği, aile ilişkilerinin (\%54) ise olumlu etkilendiği belirlenmiştir. Ayrıca, öğrencilerin \%70'nin covid-19 olma kaygısı yaşadığı ve \%40'nın bu kaygı nedeniyle sınava girmeyi düşünmediği belirlenmiştir. $\mathrm{Bu}$ süreçte öğrencilerin \%95'nin evde kalma kısıtlılığına uydukları ve \%78'nin tedbirlere uymadığı belirlenmiştir (Tablo 2). Kürtüncü ve Kurt (2020) yaptıkları nitel çalışmada, öğrenciler bu süreçte ders çalışma 
süreçlerinin, psikolojik ve sosyolojik durumlarının olumsuz etkilendiğini belirtmiş olmalarının, yanı sira ailelerin ve kendilerinin covid-19 olma korkusu yaşadıklarını ifade etmiştir (Kürtüncü ve Kurt, 2020). Ayrıca yapılan başka bir çalışmada da öğrencilerin uzaktan eğitimden memnun olmadıkları, psikolojilerinin ve sosyal yaşamlarının olumsuz etkilendiği belirlenmiştir (Yavaş Çelik, 2020).

Cao ve ark. (2020)'nın yaptığı çalışmada, öğrencilerin covid-19 hastalığ1 korkusu nedeniyle, stres yaşadıkları, psikolojilerinin bozulmuş olduğu ve ders çalışamadıkları belirlenmiştir(Cao ve ark., 2020). Covid-19 salgın sürecinde en önemli sorunlardan biri kişilerin yaşadıkları kaygılardır. Gelecekle ilgili belirsizlikler, hastalık bulaşma, bulaştırma korkusu öğrencilerin derslerine odaklanmalarını engellemiştir (Lee, 2020; Wang ve ark., 2020).

Çalışmada, bu süreçte öğrencilerin \%3'nün ve yakınlarının \%25'nin covid-19 tanısı aldığı belirlenmiştir (Tablo 2). Bu sonuç göz önüne alındığında öğrencilerin kaygılarının yersiz olmadığını söyleyebiliriz. Ayrıca her gün açıklanan vakaların giderek artması, virüsün yayılım hızının diğer virüslere göre hızlı ve ölümcül olduğu ve sınavların yapılacağ1 tarihlerin netleşmemesi, verilen tarihlerin değişmesi gibi durumların (ÖSYM, 2020) öğrencilerin anksiyete, tükenmişlik, covid-19 korkusu yaşama durumlarını arttırmış olabilir (Tablo 5). Ayrıca, salgının oluşturduğu hastalık ve ölüm korkusunun çaresizlik duygusunu tetiklemesi bu duruma katkı sağlamış olabilir (Dozois ve Rnic, 2019). Öğrencilerin anksiyete, tükenmişlik ve covid-19 korkusu yaşama durumları çalışmada yüksek olarak belirlenmiştir (Tablo 5). Salgınlar sırasında hastalanma ve ölüm korkusu, damgalanma ve çaresizlik yaşandığ 1 bildirilmiştir. Ayrıca, stres sonucunda bireylerde anksiyete, depresyon, uykusuzluk ve yorgunluk gibi tükenmişliği destekleyen durumların ortaya çıktığı bilinmektedir (Hall ve ark., 2008; Rubin ve Potts, 2010; Bie'n ve ark., 2015; Drury ve ark., 2019).

Çalışmadaki sonuçlara göre de öğrencilerin CKÖ ile MTEÖ puanları arasında zayıf, CKÖ ve YABÖ pu- anları arasında orta düzeyli pozitif yönde bir ilişki olduğu belirlenmiştir (Tablo 3)(Şekil 1 ve Şekil 2). Ayrıca, Öğrencilerin YABÖ puanlarının kesme puanlarına göre MTEÖ ve CKÖ puanları arasında anlamlılık olduğu YABÖ puanları yüksek olan öğrencilerin MTEÖ ve CKÖ puanlarının da yüksek olduğu belirlenmiştir (Tablo 4). Bu sonuçlara göre covid-19 korkusunun öğrencilerin tükenmişlik ve anksiyete durumu ile ilişkili olduğu ve anksiyetesi yüksek olan öğrencilerin covid-19 korkusu ve tükenmişlik durumlarının da fazla olduğu söylenebilir.

\section{Sonuç}

Gençlerin özgüvenini olumsuz etkileyen, kendini yalnız hissetmesine yol açan, başkalarının görüşlerine aşırı önem vermesine neden olan ve bireyselleşmeye engel olduğu bilinen üniversiteye giriş s1navı Covid-19 salgınında gençlerde daha baskı yaratan bir hal almış ve gençlerin baş edemeyeceği kaygılara neden olmuştur. Yapılan çalışmada öğrencilerin covid korkusunu yoğun olarak yaşadıkları hatta öğrencilerin çoğu bu süreçte psikolojik ve sosyolojik olarak olumsuz etkilendikleri ders çalışmada güçlük yaşadıklarını, covid-19 olup sınava girememe kaygısı yaşadıkları ve hatta öğrencilerin hastalanmaktan korktukları için sınava girmemeyi bile düşündükleri belirlenmiştir. Ayrıca, çalışmada covid-19 korkusu ile, tükenmişlik ve anksiyete durumlarının ilişkili olduğu ve anksiyetesi yüksek olan öğrencilerin covid-19 korkusu ve tükenmişliğinin daha fazla olduğu belirlenmiştir.

Bu sınava hazırlanma sürecinde intihar eden gençler bile bulunmaktadır. Gençlerin yaşamlarını oldukça etkileyen bu sınavın ölümcül bir hastalık ile engellenmesinin doğurduğu sonuçların bilinmesi gençlerin sağlığı için alınması gereken önlemler açısından önem arz etmektedir. Bu çalışma ile belirlenen sonuçlar ışı̆̆ında gereken tedbirler alınarak oldukça hassas bir gelişim döneminde bulunan ergenlerin sağlığ1 korunabilir ve bu sürecin daha rahat atlatılması sağlanabilir. Gençlerin izlemini yakından takip eden, onları tanıyan gelişim dönemine 
uygun tedavi ve bakım veren çocuk sağlığı ve hastalıkları hemşirelerine de çalışma sonuçlarının yol gösterici olacağı düşünülmektedir. $\mathrm{Bu}$ çalışma gençlerin yaşadığı yoğun kaygı ve tükenmişliği ortaya koymuştur. Bu doğrultuda hemşireler tedavi ve bakım verdikleri sınav sürecindeki gençlerin anksiyete ve kaygı düzeylerini daha çok dikkate alarak yaklaşım gösterebilirler ve gençlerin covid-19 korkusu yaşamalarını önleyici eğitimler düzenleyebilirler.

\section{Çıkar Çatışması}

Çalışma için herhangi bir çıkar çatışması söz konusu değildir. Çalışma tek kişi tarafından yazılmıştır.

\section{KAYNAKLAR}

Ahorsu DK, Lin CY, Imani V, Saffari M, Griffiths MD, Pakpour AH. (2020). The fear of COVID-19 scale: Development and initial validation. Int J Ment Health Addict 2020 Mar 27:1-9.

Bakioğlu F, Korkmaz O, Ercan H. Fear of COVID-19 and positivity: Mediating role of intolerance of uncertainty, depression, anxiety, and stress. Int J Ment Health Addict 2020 May 28 : 1-14.

Bie'n A, Rzónca E, Ka'nczugowska A, Iwanowicz Palus G. Factors affecting the quality of life and the illness acceptance of pregnant women with diabetes. Int J Environ Res Public Health. 2015;13:68.

Cao W, Fang Z, Hou G, Han M, Xu X, Dong J, Zheng J. The psychological impact of the COVID-19 epidemic on college students in China. Psychiatry Res 2020;287:112934.

Çapri B, Gündüz B, Gökçakan Z. Maslach Tükenmişlik envanteri-öğrenci formu (MTE-ÖF)'nun Türkçe'ye uyarlaması: geçerlik ve güvenirlik çalışması. Çukurova Üniv Eğitim Fak Derg 2011; 1(40):134-47.

Dozois DJA, Rnic K. Abnormal psychology perspectives. DJA Dozois (Ed.), pp. 48-61, 2019; Toronto, Pearson.

Drury J, Carter H, Cocking C, Ntontis E, Tekin Guven S, Amlôt R. Facilitating collective psycho- social resilience in the public in emergencies: Twelve recommendations based on the socialidentity approach. Front Public Health, 2019;6(7):141.

Epidemiology Working Group for NCIP Epidemic Response, Chinese Center for Disease Control and Prevention. [The epidemiological characteristics of an outbreak of 2019 novel coronavirus diseases (COVID-19) in China]. Zhonghua Liu Xing Bing Xue Za Zhi. 2020 Feb 10;41(2):145-151. Chinese.

Hall RC, Hall RC, Chapman MJ. The 1995 Kikwit Ebola outbreak: lessons hospitals and physicians can apply to future viral epidemics. Gen Hosp Psychiatry. 2008;30(5):446-52.

Ho CS, Chee CY, Ho RC. Mental health strategies to combat the psychological impact of COVID-19 beyond paranoia and panic. Ann Acad Med Singapore 2020;49(3):155-60.

Huang C, Wang Y, Li X, Ren L, Zhao J, Hu Y et al. Clinical features of patients infected with 2019 novel coronavirus in Wuhan, China. Lancet 2020;395(10223):497-506.

Kaçan Softa H, Ulaş Karaahmetoğlu G, Çabuk F. Lise son sınıf öğrencilerinin sınav kaygısı ve etkileyen faktörlerin incelenmesi. KÜ Kastamonu Eğitim Derg 2015;23(4):1481-94.

Konkan R, Şenormancı Ö, Güçlü O, Aydın E, Sungur MZ. Yaygın anksiyete bozukluğu-7 (YAB-7) testi türkçe uyarlaması, geçerlik ve güvenirliği. Nöropsikiyatri Arş 2013;50:53-8.

Kutsal D, Bilge F. A study on the burnout and social support levels of high school students. Edu Sci 2012;37(164):283-97.

Kürtüncü M, Kurt A. Covid-19 pandemisi döneminde hemşirelik öğrencilerinin uzaktan eğitim konusunda yaşadıkları sorunlar. Avrasya Sos Ekon Araş Derg (ASEAD) 2020;7(5):66-77.

Lee J. Mental health effects of school closures during Covid-19. Lancet Child Adolesc Health 2020;4(6):421.. 
ÖSYM (2020) Sınav Takvimindeki Değişiklikler. https://www.osym.gov.tr/TR,8797/takvim.ht $\mathrm{ml}$

Özbaş A, Sayın A, Çoşar B. Üniversite sınavına hazırlanan öğrencilerde sinav öncesi anksiyete düzeyi ile erken dönem uyumsuz şema ilişkilerinin incelenmesi. Psikoter Araş Derg 2012;1:81-9

Rubin GJ, Potts HW, Michie S. The impact of communications about swine flu (influenza A H1N1v) on public responses to the outbreak: results from 36 national telephone surveys in the UK. Health Technol Assess 2010;14(34):183-266.

Sahu, P. Closure of universities due to coronavirus disease 2019 (COVID-19): Impact on education and mental health of students and academic staff.

Cureus 2020;12(4):e7541.

T.C. Sağlık Bakanlığı. Covid-19 Rehberi. https://covid19bilgi.saglik.gov.tr/depo/rehbe rler/COVID-19_Rehberi.pdf. (2020, April)

Wang C, Cheng Z, Yue XG, Mc Aleer M. Risk Management of COVID-19 by universities in China. J Risk Finan Manag 2020;13(2):36.
World Health Organization. Clinical management of severe acute respiratory infection when Novel coronavirus $(\mathrm{nCoV})$ infection is suspected: interim

guidance.

https://www.who.int/internalpublications-det ail/clinicalmanagement-of-severe-acute-respira toryinfection-when-novel-coronavirus-(ncov)-infection-i s-suspected (2020 11 January).

WHO (2020, 11 March). Director-General's opening remarks at the media briefing on COVID-19. https://www.who.int/dg/speeches/detail/w ho-director-general-sopening-remarks-at-the-m edia-briefing-on-covid-19 (2020 11 March).

Viner RM, Russell SJ, Croker H, Packer J, Ward J, Stansfield C, Booy R. School closure and management practices during corona virus outbreaks including COVID-19: A rapid systematic review. Lancet Child Adolesc Health 2020;397-404.

Yavaş Çelik M. The effect of staying at home due to COVID-19 outbreak on nursing students' life satisfaction and social competencies. Perspect Psychiatr Care. 2020;1-5. 